\title{
Miranda
}

Revue pluridisciplinaire du monde anglophone /

Multidisciplinary peer-reviewed journal on the English-

speaking world

$10 \mid 2014$

Images on the Move: Circulations and Transfers in film

\section{Choreographing Genre in Kill Bill Vol. 1 \& 2 (Quentin Tarantino, 2003 \& 2004)}

\section{David Roche}

\section{OpenEdition}

\section{Journals}

\section{Electronic version}

URL: http://journals.openedition.org/miranda/6285

DOI: 10.4000/miranda. 6285

ISSN: 2108-6559

Publisher

Université Toulouse - Jean Jaurès

\section{Electronic reference}

David Roche, "Choreographing Genre in Kill Bill Vol. 1 \& 2 (Quentin Tarantino, 2003 \& 2004)", Miranda

[Online], 10 | 2014, Online since 23 February 2015, connection on 16 February 2021. URL: http:// journals.openedition.org/miranda/6285; DOI: https://doi.org/10.4000/miranda.6285

This text was automatically generated on 16 February 2021.

\section{(c) (i) () $\Theta$}

Miranda is licensed under a Creative Commons Attribution-NonCommercial-NoDerivatives 4.0 International License. 


\title{
Choreographing Genre in Kill Bill Vol. 1 \& 2 (Quentin Tarantino, 2003 $\& 2004)$
}

\author{
David Roche
}

1 While most articles on and reviews of Kill Bill have focused on genre (Le Cain 2004), gender (Coulthard 2007; Lavin 2010) and ethnicity, notably raising the question of cultural appropriation (Pang 2005; Tierney 2006; Inouye 2009; Chan 2009), that is whether or not Tarantino's attitude towards East Asian genres is colonial or on the contrary in keeping with these traditions, this article offers an analysis of the live action fight scenes in Kill Bill Vol. 1 and 2. Much of the information concerning fight choreography has been provided by a how-to-do book on the topic, written by a Chinese American stuntman and fight choreographer, John Kreng, who defines fight choreography as "the art of creating a staged and rehearsed physical conflict that is convincing to the audience for entertainment purposes" (xx). Another fight choreographer, Aaron Anderson (2005), has provided a general overview of fight choreography in order to demonstrate that "violent imagery [...] functions as one of the primary cinematic languages for character description and plot progression in modern action films." He describes Tarantino's approach in Kill Bill as one of "playful borrowing," Tarantino having designed the fight scenes, largely by himself if one is to believe David Carradine, as "multi-layered homages to other films."

2 It is this connection between fight choreography and film genre, in other words between the representation of the circulation of bodies in the film and, on the metafictional level, the circulation of references to national genres and specific movies, analyzed at length by Philippe Ortoli in his ground-breaking book (230), that will be the main focus in what follows. Clearly, the fight scenes in Kill Bill represent feats both for the Bride-in terms of the valor and number of her opponent(s) and the length of the fights-and for the cast and crew who have choreographed fights that are challenging in terms of space-fights occur in closed spaces like Vernita's house [KB1 5:45], Budd's trailer [KB2 71:39] and the Bride's hotel room [KB2 106:19]time-the twenty-minute- 
long showdown at the House of Leaves restaurant [KB1 71:21]-and action-the final swordfight with the duelists sitting around a patio table [KB2 113:34]. Yet, paying attention first to the staging, then to the camerawork, ${ }^{1}$ this article seeks to go beyond the film's show-offy veneer in order to study the way the fight scenes play an integral part in terms of narrative, dramatic and metafictional intent, and ultimately to assess to what extent the treatment of profilmic and filmographic movement, and the lack thereof, reflect the generic and cultural hybridity of two films that mix "American" and "East Asian" genres, like the Western, the gangster, blaxploitation, pirate, samurai and kung-fu movies, possibly revealing that some movements are, in effect, generic. The film's generic hybridity, of which David Carradine's star persona appears to be an embodiment-Carradine was the lead actor in the TV series Kung-Fu (Warner Bros. for ABC, 1972-1975)-bears not only on the film's aesthetics, but also on its relation to identity politics, involving binaries such as East/West and masculine/feminine.

\section{Fight choreography}

The fight scenes are characteristic of the main genres that inform the two installments: the teahouse/restaurant brawl and outdoor duel of Asian martial arts or samurai movies, and the barroom brawl and outdoor gunfight typical of the Western (Kreng 10). ${ }^{2}$ The films' generic hybridity is also reflected in the Bride's fighting style. In Kill Bill 2, a younger Beatrix Kiddo claims to be "proficient in Tiger-Crane style" and "more than proficient in the exquisite art of the samurai sword" [KB2 46:15]. The Bride, who perfected her kung-fu under the tutelage of Pai Mei, wields a samourai sword designed by Hattori Hanzo, the man from Okinawa, and as Bill's student, is presumably adept with a gun. Her hybrid style is reinforced, on a metafictional level, by the fact that her Asian masters are played by Chia-Hui Liu and Sonny Chiba, who starred in, respectively, the Hong Kong Kung-Fu movie Clan of the White Lotus (Lieh Lo, 1978), where Liu's character (Wen-Ting) kills Priest Pai Mei, and the Japanese TV series Shadow Warriors (1980) where Chiba's character was named Hattori Hanzô. Thus, the figure of the Bride represents a sort of utopian ideal, reconciling not just East and West, but two nations, China and Japan, with a history of conflict, and even different schools of Kung Fu; in this respect, she recalls Wen-Ding who, in Executioners from Shanghai (Chia-Liang Liu 1977), succeeds in overcoming Pai Mei by combining his father's Tiger boxing style and his mother's Crane boxing style.

In terms of movement, the popular notion is that kung fu is a more circular form of martial art, while karate is more linear (Green and Svinth 185, 631). Martial experts emphasize that, in actuality, both contain linear and circular techniques, but that linear techniques are more appropriate for direct attack, while circular techniques are more typical of defense. Kreng explains, however, that fight choreography often favors "wide, sweeping, circular techniques" because they are more readable in visual terms (xxi); for instance, the side kick, a very effective technique in a real fight, is not visually effective because of its linearity and requires some adjustment, such as the actor taking "a couple of quick steps prior to throwing the kick" (367). So though the predominance of circular movements in Kill Bill is somewhat justified by the Bride's having been trained by a kung-fu master, it is, no doubt, above all a question of visual efficiency.

In terms of mise en scène, the fight scenes in Kill Bill are staged according to a certain number of horizontal axes. Surprisingly, this number does not increase proportionally 
with the size of the space in which the fight occurs; for instance, there are only five axes in the outdoor duel scene between the Bride and O-Ren Ishii [KB1 88:50] as opposed to nine in the indoor scene with Elle [KB2 71:40]. The number is, however, directly correlated to the duration and tempo of the fight; this explains the smaller number of axes in the four-minute-long O-Ren scene accompanied by the midtempo flamenco rock song “Don't Let Me Be Misunderstood / Esmeralda Suite” (Santa Esmeralda, 1977). Thus, the number of axes depends, first and foremost, on the number of the Bride's opponents. For instance, the Bride's battle with the legions of Crazy 88 includes approximately sixteen axes, not including when she rotates on the dance floor [KB1 79:30]. Potentially, each new opponent offers a new axis. The number of axes is not, however, necessarily proportional to the number of opponents, since one opponent implies, de facto, one axis, while several opponents can be fought along the same axis, as in the scene where the Bride slices her way down a corridor running parallel to the main dining room in the House of Blue Leaves restaurant [KB1 80:25]. The number of axes is also contingent on the valor of her adversaries. The Bride's fights with the first six members of the Crazy 88 [KB1 72:20], and even Pai Mei's oppositions with the Bride [KB2 48:10], all involve just one axis per opponent, demonstrating the victor's indomitable superiority over his/her opponent. By way of comparison, the Bride's fights with Vernita, Gogo [KB1 75:00], O-Ren and Elle are organized along, respectively, seven, four, five and nine axes.

The Pai Mei scene in Kill Bill Vol. 2 reveals that the handling of space in the fight scenes is not limited to the use of axes, and thus is not just horizontal, but also involves the use of planes, and is thus equally vertical. Indeed, one of the reasons Pai Mei manages to maintain the same axis throughout the fight is because he escapes and sometimes attacks on another level. This is most strikingly achieved when he flies up onto the Bride's sword and tells her: "From here, you have an excellent view of my foot," before kicking her in the face [KB2 48:25]. This scene reveals through parody what was, perhaps, less obvious in the fight scene at the House of Blue Leaves: it is thanks to Pai Mei's disciple's ability to vary the planes of both attack and defense that she manages to vanquish her numerous foes. Like her master [KB2 48:20], she cartwheels over the Crazy 88's heads [KB1 81:30], the usage of slow motion combined with a wooshing sound effect highlighting their common talent. Her strategy of crouching to sever her adversary's limbs also enables her to eliminate many of the Crazy 88, particularly when they encircle her [KB1 82:30], as well as Gogo [KB1 76:50], Johnny Mo [KB1 85:10] and ORen [KB1 91:15]. More generally, the Bride takes the fight from the restaurant's first floor to the second floor mezzanine, then back to the first floor, and finally back up to the second [KB1 80:55, 81:20, 82:45].

7 This approach to fight choreography has, above all, a dramatic function. Indeed, the shift to a new axis or plane is always brought on by a movement that indicates that one of the fighters is either trying to get the upper hand or to escape because $\mathrm{s} / \mathrm{he}$ is at a disadvantage. ${ }^{3}$ This might seem absolutely natural in terms of fighting techniques-it is a basic precept of combat that you should change the axis to offset your opponent-but in a film, it has the clear advantage of dramatizing a turning point and, thus, of highlighting the dramatic structure of the fight scene. A fight scene organized along one axis would, in effect, make it less clear who exactly is getting the upper hand. Furthermore, the change from one axis to another is almost always brought on by a circular movement, such as a fighter spinning on her-/himself or stepping aside. The 
opening fight between the Bride and Vernita in Kill Bill Vol. 1, for instance, is organized in the following manner:

\begin{tabular}{|l|l|l|}
\hline Room & Axis & Move that triggers change of axis \\
\hline $\begin{array}{l}\text { Living } \\
\text { room }\end{array}$ & 1 & Vernita hurls the Bride against the wall [5:48]. \\
\hline & 2 & The Bride kicks Vernita back onto the coffee table [5:54]. \\
\hline & 3 & Vernita brings the Bride to her knees by hitting her with a table leg [5:58]. \\
\hline Kitchen & 5 & $\begin{array}{l}\text { Vernita escapes into the kitchen after pushing some shelves onto the Bride } \\
{[6: 25], \text { and swings a knife at the Bride as soon as she attempts to enter the }} \\
\text { kitchen [6:33]. }\end{array}$ \\
\hline $\begin{array}{l}\text { Dining } \\
\text { Room }\end{array}$ & 6 & $\begin{array}{l}\text { The Bride dodges Vernita's attempt to lunge at her with a knife and pushes her } \\
\text { off the dining room table [6:42]. }\end{array}$ \\
\hline $\begin{array}{l}\text { Living } \\
\text { Room }\end{array}$ & 7 & \begin{tabular}{l} 
\\
\hline
\end{tabular}
\end{tabular}

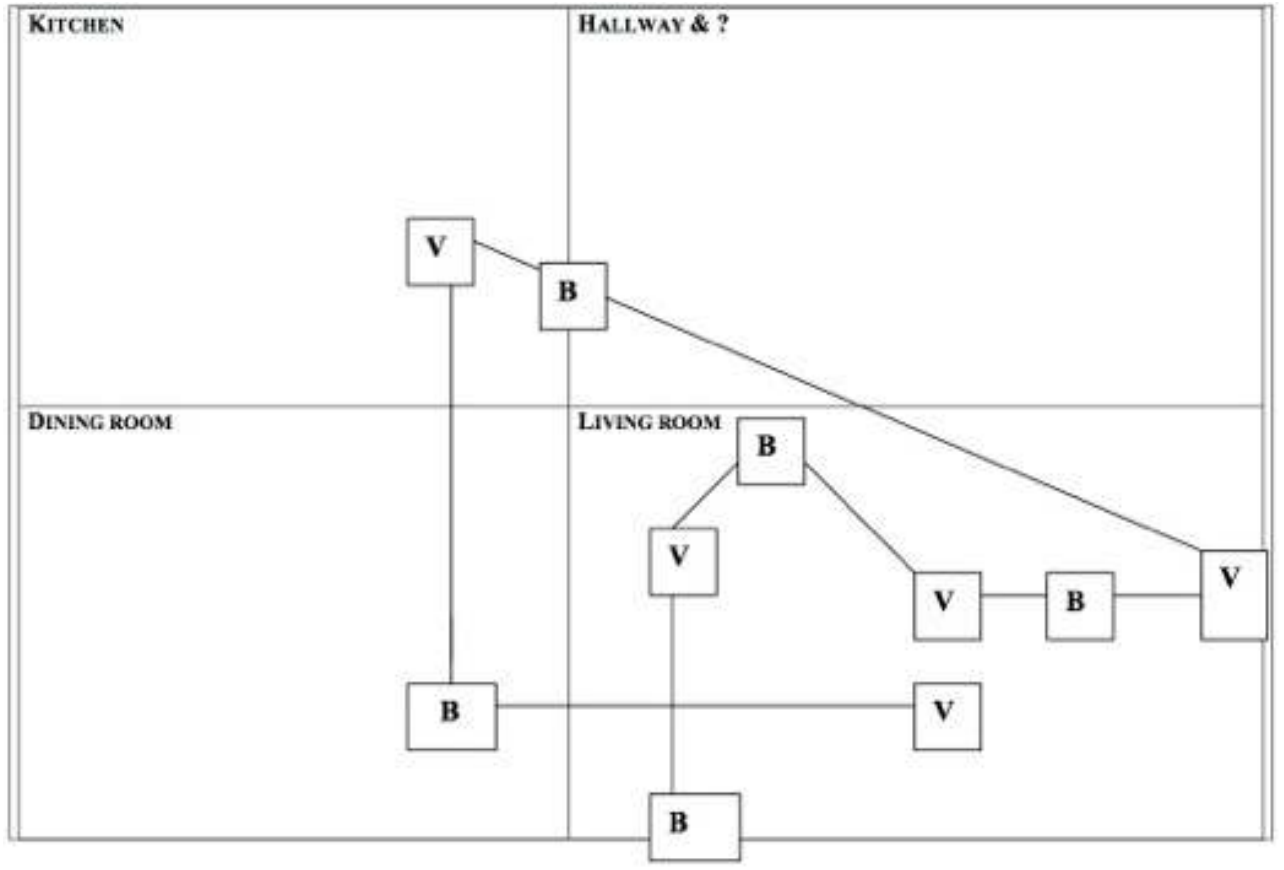

One consequence of this approach is that staging a fight according to dramatic axes can even produce irony. Indeed, the Bride's four-second-long face-off with Budd, presumably the least valiant of the Deadly Viper Assassination Squad, involves just one axis, with Budd coming out a surprise victor [KB2 24:55], the Western beating the martial arts film in this round (Le Cain 2004). This aborted fight scene foreshadows the 
films' equally ironic anti-climactic climax: the Bride's final confrontation with Budd's brother Bill involves only two axes and lasts a mere fifteen seconds [KB1 113:35].

So the staging of fight choreography in Kill Bill exploits all three dimensions of space in order to make body language readable. The number of axes and planes involved can be correlated to the dramatic potential of a given fight, notably the talent or cunning needed to overcome a given adversary, and can even produce irony. The techniques and strategies employed by the Bride also participate in her characterization: if, on a first view, Kill Bill Vol. 1 seems to be utterly lacking in this department, the analeptical Pai Mei chapter in Vol. 2 reveals that the disciple has learned from her master in order to overcome her foes in the House of Blue Leaves, confirming Anderson's reading (2005) that characterization is mainly effected "visually" thanks to violence, at least in the first installment. Finally, the staging also pertains to the metafictional dimension, as, like the Bride, it mixes strategies developed both in Hollywood Westerns (the barroom brawl) and Asian samurai and martial arts films (changing planes, linear attacks), sometimes playing various genres and cultures against each other, just as martial art films are often based on oppositions between various fighting styles (Anderson 2005).

\section{Modes of interaction between camera and body}

10 The following taxonomy aims at foregrounding the role played by the camerawork in relation to body movement.

\section{Camerawork // diegetic movement}

11 This is, by and large, the most dominant stylistic approach. It involves various shot sizes. In this case, camerawork is contingent on body language which it attempts to mimic. The camera pans or tracks right and left, and/or tilts up and down, to follow the movements of characters delivering or dodging blows, advancing on, projecting, fleeing from or being hurled by their opponents. Accordingly, the camera remains still when the fighters are still. In the opening fight scene with Vernita Green, for instance, the camera pans left and tilts down when the Bride smashes against the wall and falls to the floor [KB1 5:49], then tilts down when Vernita lands on the glass coffee table [KB1 5:54]; the fight scene ends with a lateral medium full shot where the two are poised motionless facing each other with the window in the background [KB1 6:59]. With the notable exception of the Bride's duel with O-Ren, which utilizes steady camera movements in harmony with the slow, graceful rhythm of the scene, this stylistic approach is generally combined with the usage of the handheld camera. David Bordwell has noted that, "[s]ince the 1920s, handheld shots [have been] usually associated with violence" (The Way 144), and that the handheld camera is prevalent in contemporary film style, filmmakers believing that "virtually any scene could benefit from the handheld shot's immediacy, urgency and (the inevitable word) energy" (The Way 145). That said, Kill Bill very rarely employs a shaky handheld camera and favors steady movements that are more readable for the viewer. Shaky handheld shots can, however, serve to dramatize grappling scenes, which can be difficult to make engaging in film (Kreng 32), as the combatants hardly move in space though they continue to struggle. This strategy is employed when the Bride gets Vernita in a chokehold [KB1 6:05], when 
Pai Mei has blocked the Bride's right arm [KB2 50:10] and when the Bride stuffs Elle's head down the toilet ${ }^{4}$ [KB2 73:22].

\section{Camerawork $\neq$ diegetic movement}

\section{Camerawork is static while fighters move}

This is the second most frequent stylistic approach. It mainly involves full and long shots. The static full shots seem to suggest the ease with which Pai Mei flies over the Bride or knocks her down [KB2 48:20, 49:52], or that with which she eliminates the second, third and fourth members of the Crazy 88 [KB1 72:45, 73:18]; indeed, there are practically no static shots when she fights against the rest of the yakuza gang. Static shots can also serve to frame bodily movements. This is especially the case in the shadow-play-like scenes where we see the Bride training with Pai Mei [KB2 52:44, 53:20] or defeating the seven remaining members of the Crazy 88 in the private dining room [KB1 83:34], with black silhouettes against blue or red backgrounds reminiscent of the opening credits of Samurai Fiction: Episode One (Hiroyuki Nakano, 1998); the black grid on the blue background even provides a template thanks to which coordinates can be given to the fighters' moves. What the shadow play foregrounds is that, when framed by static shots, body movements stand on their own, implying that such movements have really been effected by the stuntmen and/or actors, thereby establishing the scene's naturalism. Static shots of moving bodies-especially lateral shots-date back to the origins of cinema, when Eadweard Muybridge in 1878 and Etienne Marey in 1882 used film as a means to study the movements of horses and birds (Sklar 6; Thompson and Bordwell 5). Such shots, which are used repeatedly in Kill Bill Vol. 1 (Ortoli 229), are more common in Asian martial arts films, where, since Bruce Lee, performers have been more proficient in martial arts, opera and dance than in Hollywood films (Kreng 42-43). Kill Bill respects this tradition, as the Crazy 88 are portrayed by a fight team put together by Chinese fight choreographer Yuen Wo-Ping.

Conversely, static shots can also underline the artificiality of certain stunts. This occurs, for instance, when the Bride flies through the trailer door to attack Elle [KB2 71:40], and soon after when Elle attempts to deliver a flying jump kick [KB2 73:04]: in the first case, the camera is stuck to the Bride's feet; in the second, we have a lateral full shot of Elle. Similar shots occur when the Bride flies backward after getting kicked by Gogo [KB1 $76: 24$ ], and when the camera is attached to the chair leg the Bride kills Gogo with [KB1 76:59], to the flying ax [KB1 80:07] or to the body of the Crazy 88 whose head she has stuck a flying ax in [KB1 80:16]. These shots foreground exactly what most camera angles and movements and editing cuts conceal: the artifice. In so doing, they fulfill both a (non-negative) comic and metafictional function that, according to Margaret Rose, is typical of postmodern parody (257). ${ }^{5}$

\section{Camerawork moves though fighters do not}

Here, camerawork plays, above all, a dramatic function. This is especially the case when pauses occur during combat, for instance, when the Bride waits before killing the fifth member of the Crazy 88 [KB1 73:14], when the rest of the Crazy 88 have arrived [KB1 78:54], or when she pauses before rolling around on the floor to cut their limbs off 
[KB1 82:11]. In all three cases, such moments convey the idea that the Bride is sizing up her adversary and determining their positions in space, which is confirmed by her use of the blade of her sword as a mirror in the second example [KB1 79:14]. In other words, they dramatize the moment when the combatant determines his/her strategy. These shots are also typical of East Asian films, as "Li Hanxiang's famous 'bird's-eye fighting shot' [...] can be found in Japanese cinema as early as 1943 in Akira Kurosowa's first film, Sanshirô Sugata [sic]" (Pang 145).

15 Another frequent device is the utilization of the zoom which plays both a dramatic and a metafictional function. Like the slow pan, the slow zoom can serve to dramatize the moment before the attack when each combatant is in guard sizing the other up, for example, before the Bride and O-Ren's fight [KB1 89:30] or before the Bride and Elle's final clash [KB2 76:30]. It is also used when Pai Mei provokes the Bride [KB2 46:35] or to establish a contrast between the two after Pai Mei has scolded the Bride for having momentarily given up trying to punch through a wooden board from a distance of eight centimeters [KB2 52:19].

Quick zooms are used with more variety. They can serve to announce the arrival of a foe-Johnny Mo [KB1 78:21] or the Bride [KB2 71:40]-his/her departure-O-Ren walking away from the railing [KB1 81:37]-an impending attack-by Gogo [KB1 75:22] or Johnny Mo [KB1 84:42] -or to indicate the pain inflicted by a weapon-for instance, when the Bride gets cut by Gogo's ball [KB1 76:33] or shot at by Budd [KB2 24:55], or when Elle gets her right eye plucked out by Pai Mei and her left eye by the Bride [KB2 74:45, 76:35]. Clearly, the quick zoom attempts to evoke a character's emotions-usually surprise, fear and pain-and is, as such, a marker of subjectivity, regardless of whether it zooms in on the surprised subject (the Bride and Elle) or on the object of his/her surprise (Johnny Mo, Gogo, Budd). The quick zoom also has relevance in terms of metafiction, insomuch as it is typical of Asian martial arts films. Hence, their abundance in the Pai Mei chapter (where there are fourteen quick zooms in all) and frequent association with Shaw brothers' regular Chia Hui Liu. ${ }^{6}$ Its utilization in Kill Bill 2, namely with Budd, the cowboy, and Elle, the pirate, is, then, a mark of generic hybridity.

\section{Camerawork offsets bodily movement (or vice versa)}

This is by far the least frequent strategy. Generally speaking, it tends to draw attention to the gap between staging and camerawork, and thus to the artifice. A rare device is the use of the quick zoom in tandem with a blow. This occurs in the Pai Mei sequence when he punches a hole in a board, and later when the Bride tries to imitate him [KB2 51:05, 51:50]. In a sense, one could argue that the camerawork is nonetheless mimicking body movement-that of a fist striking the board-but the zoom is coming to meet Pai Mei's fist as it strikes the board from the other side. For this reason, I would argue that, like the other zooms, it functions as a marker of subjectivity, since it underlines the blow's impact on the board the same way some zooms recoil from a wound inflicted on bodies. Unlike the static shots of flying bodies, then, it foregrounds not so much the artifice of the staging as the artifice of the camerawork: in attempting to compensate for the fact that Pai Mei's right fist is concealed by the board, the zoom draws attention to what impedes our vision of the blow-the choice of an angle from behind the board.

Another strategy that is used sparingly are camera movements which move in different, sometimes opposite directions from the diegetic bodies. It is employed, in 
particular, when the Bride fights the legions of Crazy 88, for instance when the camera pans right to follow an opponent the Bride has just kicked in the belly while she swings her sword at a foe to the left [KB1 80:21], or when the camera tilts down to stay on her adversary's sword when the Bride leaps onto his shoulders [KB1 80:40]. The camera movements suggest, here, not only the chaos of the scene, but their utter failure to keep up with the Bride who has already effected another technique and/or moved on to another adversary: thus, the character's movements prevail over the film's, presenting a new facet of the Bride's utopian potential.

19 Finally, I would argue that the utilization of slow motion, which nowadays is sometimes effected at the editing stage, equally offsets bodily movements. It has both a dramatic and a metafictional function. First, it allows for time to admire a particular feat-Gogo, the Bride and Pai Mei leaping and spinning in the air [KB1 75:30, KB1 75:55, KB1 81:32, KB2 49:50]-heighten the sense of danger-Gogo's flying ball [KB1 76:36] or the flying ax [KB1 80:10]-highlight an important stage in the combat-Johnny Mo wounding the Bride's belly [KB1 79:50], the Bride getting up to receive O-Ren's death blow [KB1 90:40], the cut on Elle's left cheek the Bride made with a TV antenna [KB2 71:56] -or a change in tempo-when the Bride pauses before cutting off their limbs [KB1 82:25]. Second, in the scenes where the characters are endowed with quasi-magical powers, it foregrounds the artificiality of the staging-they are attached to strings-by foregrounding the artificiality of the camerawork; this artificiality is often stressed by the use of an eerie sound effect on the soundtrack. The usage of slow motion is largely borrowed from the aesthetics of Asian martial art movies that glorify physical and spiritual grace rather than violence, although it is equally prevalent in contemporary films which, since the 1980s, have been influenced by music video aesthetics (Bordwell, The Way 122).

\section{Camerawork conceals movement}

According to Kreng, one of the main issues at stake in fight choreography is the choice of camera angles (xxv). Lateral shots, as we have seen, tend to provide evidence of the diegetic movements involved. In order to avoid a visual miss, which occurs when "space (or light)" is "left between the technique and the opponent's targeted body part," specific camera angles are chosen to conceal the actual blow and make a near miss look like a virtual hit (Kreng 375). Thus, any lateral or posterior shot of the character receiving a blow conceals the wound inflicted on him, the victim's body, as well as other profilmic elements, impeding vision. This is the case of the previously mentioned six-second-long static frontal shot from behind the staircase when the Bride kills the second, third and fourth members of the Crazy 88 [KB1 72:45].

\section{The Deconstructive Potential of Generic Circulations}

If the fight scenes in Kill Bill clearly represent feats both for the heroine and for the cast and crew, they also play an integral part in the narrative by contributing to characterization and building up dramatic and ironic intent. Both diegetic and camera movements reveal many of the characteristics of fight choreography and some of specific national genres. In terms of style, the utilization of static full and long shots, the zoom-in and, to a lesser extent, slow motion, is more typical of Asian martial arts 
films than of contemporary Hollywood action movies, which rely on closeups, wipebys ${ }^{7}$ and fast-paced editing (Bordwell, The Way 137; Kreng 63). The devices employed in Kill Bill seek to make the fight scenes readable in terms of movement, space and timing, while reminding the viewer now and again of the artifice at work on all levels of the filmmaking process with comic effect. In so doing, these scenes aim to simultaneously foreground, and tap into, a series of apparently contradictory pleasures: immersion and distance, in other words, the pleasure of seeing that most of the moves have really been effected by stuntmen and actors, and that of seeing that some of these effects are just that-special effects. These pleasures are, no doubt, typical of action movies.

The film's generic hybridity, of which the most salient feature is, perhaps, the soundtrack (Ortoli 331, 360), likewise seeks to reconcile "apparent" opposites-the Western and the martial arts movie, Chinese kung fu and Japanese samourai traditions, and, of course, masculinity and femininity-most paradigmatically in the character of the Bride. Critics like Sean M. Tierney have taken issue with Tarantino's depiction of the ease with which the white character appropriates foreign traditions, thereby asserting ethnic superiority over the Asian characters (608-9). Yet Tierney not only forgets that the most ethnically hybrid character, the Japanese Chinese American ORen, is also shown to master "Western" technology in the animation scene where she acts as a sniper [41:03], but by positing "an exclusive difference" (616), he tends to reinstate an essentialist approach to race and ethnicity which the theoretical framework he rightly relies on is meant to critique. This is why I would like to end by insisting on the word "apparent." Kill Bill is a fantasy that reveals that these generic binaries are, in effect, gendered, racialized, national, in short, cultural, historical and constructed, but it also foregrounds the historical, cultural and aesthetic circulations that link apparent opposites, thereby deconstructing rigid dichotomies: Japanese karate was influenced by Chinese and Southeast Asian martial arts (Green and Svinth 206), but Hong Kong cinema was influenced by Japanese cinema (Pang 144); Japanese samourai movies were influenced by the Hollywood Western which they, in turn, influenced, as well as providing material for George Lucas when making Star Wars ${ }^{8}$ (1977); Italian Westerns drew on the Hollywood Western which they, in turn, influenced, while drawing on Asian samurai and martial arts in films like Red Sun (Terence Young, 1971) and Shangaï Joe (Mario Caiano, 1973); and perhaps the most famous case of transnational circulation, that of film noir, a term first used by French critics to designate American films, which has come to be quasi-exclusively associated with American cinema, even though France has its own history of noir films (Pillard 2012). ${ }^{9}$

Maximilian Le Cain (2004) has described Kill Bill as Tarantino's "own personal digest of film history." The final montage scene of Vol. 1 exemplifies the way this generic hybridity evidences the cultural circulations at work in film history [94:35]. With for musical backdrop a Japanese ballad ${ }^{10}$ drawn from the film score of Lady Snowblood (Fujita Toshiya, 1973), the tale of Kashima Yuki's quest to avenge her family, an obvious hypotext for Kill Bill, the Bride, dressed up in her yellow-and-black-Bruce-Lee-in-Gameof-Death (Robert Clouse, 1978) suit, making her look a bit like a Power Ranger (Saban Entertainment, 1993-2002), a Japanese franchise that was purchased by Disney (2003-2010) and that itself descends from The Space Sheriff (Toei Co., 1982-), in which Sonny Chiba played a former Space Sheriff, gives her instructions to the aptly named French Japanese femme fatale Sofie Fatale, speaking in a muffled deadpan voice à la Clint Eastwood or Sony Chiba, yet through a black vizor like Darth Vader, in a scene 
that recycles the situation-a body in a trunk-and the technique-the low-angle shot and high-angle reverse shots-used in Reservoir Dogs (1992) and Pulp Fiction (1994), with female characters in place of male ones. The Japanese hypotext, Lady Snowblood, which already subverts the masculine codes of the samurai genre, authorizes this replacement of the male characters by female characters, and of the castrating father by a castrating mother, in an American film, whose own national purity is compromised by the presence of these hybrid characters, and through the many references to other cinemas and to the most famous Chinese American martial actor, Bruce Lee, whom, on the metafictional level, the Bride avenges by killing Bill, portrayed by David Carradine, who was given Lee's part in Kung Fu because producers thought Americans were not ready for an Asian American hero (Tierney 612; Kreng 37). ${ }^{11}$ Clearly, Kill Bill offers ample proof that generic circulations, conceived as much as diegetic, aesthetic and transnational movements, are, in effect, endowed with both aesthetic pleasure and political potential.

\section{BIBLIOGRAPHY}

Anderson, Aaron. "Mindful Violence: the Visibility of Power and Inner Life in Kill Bill." Jump Cut 47 (2005). Electronic. Seen on October 15, 2013.

Bordwell, David. Narration in the Fiction Film. Madison, WI: University of Wisconsin Press, 1985.

---. The Way Hollywood Tells It: Story and Style in Modern Movies. Berkeley, L.A. and London: University of California Press, 2006.

Coutlhard, Lisa. "Killing Bill: Rethinking Feminism and Film Violence." In Interrogating PostFeminism. Eds. Yvonne Tasker and Diane Negra. Durham, NC: Duke University Press, 2007. 152-75. Green, Thomas A. and Joseph R. Svinth, Eds. Martial Arts of the World: An Encyclopedia of History and Innovation. Santa Barbara, CA, Denver, CO and Oxford, UK: ABC-CLIO, 2010.

Inouye, Charles Shiro. "Promoting Virtue and Punishing Vice: Tarantino's Kill Bill and the Return of Bakumatsu Aesthetics.” Post Script 28.2 (Spring 2009): 92-100.

Kill Bill Vol. 1. Dir. Quentin Tarantino, Miramax and A Band Apart, 2003. DVD. TF1 Vidéo, 2003.

Kill Bill Vol. 2. Dir. Quentin Tarantino, Miramax and A Band Apart, 2004. DVD. TF1 Vidéo, 2004.

Kreng, John. Fight Choreography: The Art of Non-Verbal Dialogue. Stamford, CT: Cengage Learning PTR, 2007.

Lavin, Maud. Push Comes to Shove: New Images of Aggressive Women. Cambridge, MA: The MIT Press. Le Cain, Maximilian. "Tarantino and the Vengeful Ghosts of Cinema." Senses of Cinema 32 (2004). Electronic. Seen on October 15, 2013.

Ortoli, Philippe. Le Musée imaginaire de Quentin Tarantino. Paris: Cerf-Corlet, 2012.

Pang, Laikwan. “Copying Kill Bill.” Social Text 23.2 (Summer 2005): 133-50. 
Pillard, Thomas. "Une histoire oubliée : la genèse française du terme « film noir » dans les années 1930 et ses implications transationales." Transatlantica 11.1 (2012). <http:// transatlantica.revues.org/5742>. Seen on June 9, 2013.

Rose, Margaret A. Parody: Ancient, Modern and Post-modern. Cambridge: Cambridge University Press, 1993.

Sklar, Robert. Movie-Made America: A Cultural History of American Movies (Revised and Updated). 1975. New York: Vintage Books, 1994.

Thompson, Kristin and David Bordwell. Film History: An Introduction. 3rd Edition. 1994. New York: McGraw Hill International Edition, 2010.

Tierney, Sean M. “Themes of Whiteness in Bulletproof Monk, Kill Bill, and The Last Samourai." Journal of Communication 56 (2006): 607-24.

\section{NOTES}

1. More space would have been necessary to study the relationship between the rhythm of the fights, the editing and the soundtrack.

2. One could obviously add the swordfight on a ship in a pirate film.

3. This confirms Ortoli's comment that, like Bruce Lee in Fists of Fury (Wei Lo and ChiaHsiang Wu, 1971), the Bride "directs the centripetal or centrifugal attributes of the geometric figure with her sword" in the scene where she is surrounded by the Crazy 88 (285, my translation).

4. For Anderson (2005), this scene emphasizes how "masculine" their brawl is.

5. Rose argues that "only works or theories of parody may be described as 'post-modern' which have (1) overcome both (a) the modern reduction of parody to either the meta-fictional or the comic and (b) the modern understanding of the comic as something negative, and (2) followed the 'modern' period and its works in time, and with some conscious transformation of modernist principles."

6. In films like The 36th Chamber of Shaolin (Chia-Liang Liu, 1978), zooms are used in place of cuts even in scenes that are not action scenes. American films, it seems to me, tend to favor push-ins.

7. Apart from the chokehold scene with Vernita or when the Bride and Elle wrestle, one of the rare instances of a wipeby occurs right after a member of the Crazy 88 gets projected [KB1 81:41] or before the Bride starts rolling on the floor [KB1 82:27].

8. George Lucas has recognized The Hidden Fortress (Akira Kurosawa, 1958) as an influence for Star Wars.

9. Jean-Pierre Chartier's famous 1946 essay was called "Les Américains aussi font des films noirs" (my italics). Moreover, Jean-Pierre Melville’s Le Samouraï (1967), which was influenced by Eastern lore, heavily influenced Hong Kong films like The Killer (John Woo, 1989).

10. "Flower of Carnage (Shura No Hana)" is the theme song of the 1973 film but was performed by Meiko Kaji in Kill Bill Vol. 1 .

11. Considering Tarantino's knowledge of film history, I seriously doubt that he sees David Carradine as a martial arts expert of the ilk of Sonny Chiba or Bruce Lee, as Sean M. Tierney seems to believe (612). 


\section{ABSTRACTS}

The following analysis of the live action fight scenes in Kill Bill attempts to show that they play an integral part in terms of narrative, dramatic and metafictional intent, and ultimately to assess to what extent the treatment of profilmic and filmographic movement, and the lack thereof, reflect the generic and cultural hybridity of two films that mix "American" and "East Asian" genres.

Cette analyse des scènes de combat de Kill Bill vise à montrer que celles-ci contribuent intégralement aux visées narrative, dramatique et métafictionnelle des films, et à déterminer dans quelle mesure le traitement du mouvement (et de son absence) aux niveaux profilmique et filmographique reflète l'hybridité générique et culturelle de films qui mêlent des genres "hollywoodiens" et "asiatiques".

\section{INDEX}

Keywords: fight choreography, film genre, hybridity, Kill Bill, martial arts film, movement Mots-clés: Kill Bill, chorégraphie de combat, films d'arts martiaux, mouvement, genre filmique, hybridité

\section{AUTHORS}

\section{DAVID ROCHE}

Université de Toulouse -Jean Jaurès

Professor

mudrock@neuf.fr 